\title{
PENANGANAN DAN DIVERSIFIKASI PRODUK OLAHAN KERANG HIJAU
}

\author{
Murdinah*)
}

\begin{abstract}
ABSTRAK
Kerang hijau merupakan salah satu komoditas dari kelompok kekerangan (shellfish) yang sudah dikenal masyarakat, selain kerang darah (Anadara granosa), kijing Taiwan (Anodonta $s p$ ), dan kerang bulu (Anadara inflata). Kerang hijau telah berhasil dibudidayakan dan dapat dipanen setelah 6-7 bulan. Potensi kerang hijau di Indonesia cukup tinggi dan tersebar di beberapa perairan di Indonesia. Kerang hijau mengandung protein sekitar 16,7-21,9\%, kaya akan asam amino esensial (arginin, leusin, lisin) dan mengandung mineral kalsium, fosfat, yodium, tembaga. Kerang hijau mengandung daging sekitar $30 \%$ dari bobot keseluruhan dan mempunyai nilai gizi yang tinggi, dengan demikian kerang hijau berpotensi sebagai sumber protein hewani yang relatif murah dibanding ikan. Penanganan terhadap kerang hijau agar aman dikonsumsi dapat dilakukan dengan cara pengurangan kandungan logam berat dengan perendaman dalam larutan kitosan 1,5\% selama 3 jam dan teknik depurasi untuk menurunkan kandungan bakteri kerang hijau. Diversifikasi produk olahan merupakan salah satu cara untuk meningkatkan konsumsi kerang hijau di masyarakat dalam rangka meningkatkan asupan protein dan meningkatkan pendayagunaan hasil perikanan untuk diolah menjadi produk baru sebagai makanan bernilai gizi tinggi, enak, murah, dan mudah didapat. Produk inovatif olahan kerang hijau diantaranya kamaboko, kerupuk, kerang rebus dengan pewarna alami, hidrolisat protein, dan pasta condiment. Produk inovatif kerang hijau tersebut mempunyai peluang dikembangkan menjadi komoditi ekspor.
\end{abstract}

\begin{abstract}
The handling and diversification of green mussel's products. By: Murdinah
Green mussel is one of the leading commodities of shellfish group. It has also been successfully cultivated and harvested within 6-7 months. The ubiquity of green mussel in Indonesian water, makes it has an enormous potency to be further developed. Green mussel contains $16.7-21,9 \%$ of protein, $30 \%$ of meat and rich in essential amino acids and minerals. These high nutritive values make the green mussel prospective to be utilized as the source of protein. The handling of green mussel for safe consumption could be carried out by reducing the heavy metals content and bacterial content using chitosan solution 1.5\% for 3 hours and depuration method, respectively. The diversification of green mussel's products is a possible effort to increase the protein intake in the community through the development of nutritious, delicious and inexpensive fishery products. The innovative products of green mussel that have been developed are kamaboko, crackers, boiled-mussel, protein hydrolisate and condiment paste. These products are expected to be developed for export commodities.
\end{abstract}

\section{KEYWORDS: Green mussel, handling, diversification products}

\section{PENDAHULUAN}

Indonesia sebagai negara kepulauan mempunyai potensi yang besar pada sumberdaya kekerangan (Dharma, 1988; Arifin \& Setyono, 1992). Namun demikian potensi sumberdaya kekerangan yang besar tersebut belum dikelola dan dimanfaatkan secara optimal. Mengingat kandungan gizinya yang sangat tinggi, sudah saatnya sumberdaya kekerangan ini dikelola dan dimanfaatkan untuk kesejahteraan masyarakat Indonesia (Dody, 2004). Perubahan pola makan masyarakat dunia dari mengkonsumsi daging merah (ayam, sapi, babi) ke daging putih (produk perikanan) juga memberikan peluang yang sangat baik untuk mengembangkan usaha di bidang perikanan khususnya budidaya kekerangan. Produksi kekerangan di Indonesia masih didominasi oleh hasil tangkapan alam, dan jenis kerang darah (Anadara sp) masih menduduki rangking pertama $(73 \%)$ dari total produksi kekerangan di Indonesia (FAO, 1996).

Di Indonesia beberapa jenis kekerangan telah berhasil dibudidayakan, baik dalam skala rumah tangga (kecil), maupun skala industri (besar). Budidaya skala rumah tangga pada umumnya dikembangkan untuk memenuhi kebutuhan pasar lokal, misalnya budidaya kerang darah dan kerang

\footnotetext{
*) Peneliti pada Balai Besar Riset Pengolahan Produk dan Bioteknologi Kelautan dan Perikanan
} 
hijau. Sedangkan budidaya skala industri biasanya bertujuan untuk memenuhi kebutuhan ekspor, misalnya kerang mutiara, siput loka, dan abalon.

Keberadaan kerang hijau sebagai makanan yang lezat dan sehat telah lama dikenal sejak jaman Romawi dan Indian Maya. Pemanfaatannya sebagai komoditas perdagangan mulai berkembang di awal abad ke-13 M, yaitu sejak dimulainya budidaya kerang, antara lain di Cina dan Perancis. Perdagangan kerang di negara Perancis sepanjang tahun 2004-2005 sudah menunjukkan peningkatan sebesar $30 \%$ (O Sullivan, 2003).

Potensi kerang hijau di Indonesia cukup tinggi sebagai sumber makanan masyarakat. Cilincing sebagai salah satu kecamatan terluas di Kotamadya Jakarta Utara $(27,6 \%$ dari luas seluruh wilayah Jakarta Utara) telah berkembang menjadi sentra industri budidaya dan pengolahan kerang. Tercatat 38 lapak (tempat pendaratan kerang), dengan volume produksi sekitar 3-5 ton per bulan atau $100-150 \mathrm{~kg}$ per lapak per hari (Anon., 2006a).

Kerang hijau merupakan salah satu sumberdaya perikanan yang berpotensi tinggi untuk dikembangkan di Indonesia. Teknik budidayanya mudah dikerjakan, tidak memerlukan modal yang besar dan dapat dipanen setelah berumur 6 sampai 7 bulan. Budidaya kerang hijau berkembang pesat di pantai utara Pulau Jawa. Di Kabupaten Cirebon kini berkembang 645 unit bagan untuk budidaya kerang hijau yang dimiliki oleh 538 nelayan (Anon., 2006b). Produksi kerang hijau di Cirebon merupakan yang terbesar di Jawa Barat, hingga 90 persen dari total produksi Jawa Barat. Adapun pertumbuhan produksi tahun 2006-2007 naik 15 persen dari 10.256 ton menjadi 11.859 ton (Anon., 2008). Di Propvinsi Banten sampai saat ini terdapat 208 unit bagan tancap di perairan Panimbang dengan kapasitas produksi sebesar 3.120 ton (Anon., 2006c).

Daging kerang hijau merupakan sumber protein dan mineral. Daging kerang hijau sangat lunak dan berair, dan daging yang segar umumnya berwarna putih atau orange mengkilap (Asikin, 1982). Harga kerang hijau relatif lebih murah dari pada ikan, tetapi memiliki nilai gizi yang tinggi. Dilihat dari sumber energi, kandungan protein kerang hijau $21,9 \%$; lemak $14,5 \%$; dan karbohidrat $18,5 \%$; ini setara dengan kandungan gizi daging sapi dan telur ayam. Jadi tidak heran jika kerang hijau menjadi salah satu menu favorit restoran-restoran makanan laut (Anon., 2009a). Kerang hijau dapat dimanfaatkan sebagai alternatif sumber protein hewani selain ikan-ikan pelagis yang selama ini mendominasi dalam kegiatan ekspor perikanan Indonesia.
Pemanfaatan kerang hijau saat ini sebagian besar dipasarkan dalam bentuk segar atau dikeringkan. Usaha untuk meningkatkan nilai ekonomi kerang hijau belum banyak dilakukan, padahal produksinya cukup tinggi. Diversifikasi pengolahan kerang hijau menjadi produk baru yang bernilai gizi tinggi dan disukai konsumen merupakan salah satu cara untuk meningkatkan konsumsi kerang di masyarakat, dalam rangka meningkatkan asupan protein selain itu juga dapat meningkatkan nilai tambah kerang hijau. Cara penanganan kerang hijau seperti metode pengurangan kandungan logam berat dengan perlakuan asam, kitin/ kitosan, EDTA, dan teknik depurasi untuk mengurangi jumlah bakteri dalam daging kerang telah banyak diteliti. Di samping itu, pengembangan produk baru dari kerang hijau menjadi kamaboko, hidrolisat protein, pasta condiment, kerupuk, dan kerang rebus dengan pewarna alami telah dilakukan untuk meningkatkan pemanfaatan kerang hijau sebagai sumber protein. Produk inovatif olahan kerang yang mulai banyak berkembang saat ini diharapkan dapat diterima oleh masyarakat dan dapat digunakan sebagai sumber protein.

\section{DESKRIPSI KERANG HIJAU}

Di Indonesia, kerang hijau memiliki beberapa nama lokal, seperti kijing (Jakarta), kemudi kapal (Riau), dan kedaung (Banten). Kerang hijau di Malaysia disebut siput sidu, di Singapura dikenal dengan nama Tam Chay atau Chai Luan, di Pilipina disebut Tahong dan di Thailand disebut Hoimongpo (Kastoro, 1982). Kerang hijau tersebar di beberapa perairan di Indonesia antara lain di sepanjang pantai Kepulauan Riau, Teluk Ketapang, Teluk Banten, Teluk Jakarta, dan Mauk Tangerang. Kerang ini juga terdapat di Malaysia, Cina, Thailand, Philipina, Singapura, sepanjang pantai India, Srilanka, dan Perancis (Sanusi et al., 1964). Kerang hijau hidup subur di Indonesia pada muara-muara sungai dan hutan-hutan bakau, dengan kondisi lingkungan dasar perairan berlumpur campur pasir, cahaya dan pergerakan air cukup, dengan kadar garam tidak terlalu tinggi (Kastoro, 1982).

Secara umum kekerangan merupakan kelompok hewan tidak bertulang belakang (avertebrata), sebagian besar dicirikan dengan adanya cangkang yang melindungi tubuhnya, dan hanya sebagian kecil jenis yang tidak bercangkang. Hewan yang bercangkang ganda disebut sebagai kerang (bivalvia) sedangkan yang bercangkang tunggal disebut siput (gastropoda). Secara umum bagian tubuh kekerangan dibagi menjadi lima, yaitu kaki (foot byssus), kepala, (head), bagian alat pencernaan 
dan reproduksi (visceral mass), selaput (mantle), dan cangkang (shell).

Kerang hijau merupakan salah satu jenis kerang yang termasuk dalam golongan molluska bercangkang dua (bivalvia), dengan insang berlapis-lapis (lamellibranchia), berkaki kapak (pelecypoda), dan umumnya hidup di laut. Kerang hijau memiliki warna cangkang bagian luar yang khas mulai dari hijau tua sampai coklat. Cangkang bagian luar terdapat garisgaris lengkung yang bentuknya mengikuti pinggiran cangkang. Kerang hijau dewasa memiliki ukuran panjang 4-6 cm dengan lebar yang biasanya setengah dari ukuran panjangnya (Asikin, 1982). Klasifikasi kerang hijau menurut Asikin (1982) adalah sebagai berikut: Phyllum: Mollusca; Kelas: Pelecypoda (Lamellabranchia); Kelompok: Filibranchia; Sub kelompok: Anysonyaria; Suku: Mytilidae; Marga; Mytilus; Jenis; Mytilus viridis. Dari marga Mytilus terdapat dua genus yaitu Mytilus viridis dan Perna viridis

\section{NILAI GIZI KERANG HIJAU}

Kekerangan merupakan jenis makanan laut yang banyak digemari oleh konsumen karena kelezatan rasanya dan mengandung nilai gizi yang tinggi. Bahkan beberapa jenis kerang dipercaya bisa meningkatkan stamina, misalnya daging kima dan abalon. Kerang hijau merupakan salah satu komoditas dari kelompok shellfish yang sudah dikenal masyarakat, di samping kerang darah (Anadara granosa), kijing Taiwan (Anodonta sp), dan kerang bulu (Anadara inflata). Kerang hijau Perna viridis merupakan salah satu jenis kerang yang dikenal memiliki nilai ekonomis dan kandungan gizi yang sangat baik untuk dikonsumsi. Kerang ini mengandung air $40,80 \%$; protein $21,9 \%$; lemak $14,5 \%$; karbohidrat $18,5 \%$; dan abu $4,3 \%$; dalam 200 gram daging mengandung 300 kalori. Dari nilai gizinya menjadikan kerang hijau sebanding dengan daging sapi, telur, daging ayam (Anon., 2009b). Karena itu, kerang hijau merupakan sumber protein yang bermutu tinggi dan relatif murah. Protein sangat dibutuhkan oleh tubuh manusia. Protein dibutuhkan dalam penerjemahan kode-kode genetika khususnya dalam pewarisan sifat-sifat keturunan, dan proses pembentukan sel-sel baru. Selain sebagai sumber protein yang tinggi kerang hijau dapat dijadikan kudapan kuliner yang menggoda selera. Sedangkan Chen (1977) melaporkan bahwa kerang hijau kaya akan asam amino esensial, terutama arginin, leusin, lisin. Di samping itu, daging kerang hijau lebih banyak jika dibandingkan dengan kerang-kerangan lainnya (misalnya kerang bulu, kerang darah, kerang gelatik). Kerang hijau mengandung daging lebih kurang $30 \%$ dari bobot keseluruhannya. Komposisi proksimat kerang hijau sangat beragam, hal ini tergantung dari spesies, jenis kelamin, umur, musim dan habitat (Zaitsev et al., 1969). Dore (1991) mengemukakan, komposisi nilai gizi dari kerang hijau (Mytilus viridis) seperti disajikan pada Tabel 1.

Salah satu mineral utama yang dikandung oleh kerang hijau dan dibutuhkan oleh tubuh adalah kalsium (133 mg) dan fosfor (170 mg). Keberadaan kalsium dalam sel-sel otot jantung sangat penting. Apabila kandungan kalsium tidak mencukupi, sel-sel jantung manusia tidak mampu berkontraksi dan berkembang sebagaimana mestinya (Anon., 2006d). Karakteristik daging kerang hijau selain kandungan proteinnya yang tinggi, warna dagingnya yang putih sampai kuning cerah serta aromanya yang khas, menjadikan daging kerang hijau sangat potensial untuk bahan dasar pembentukan flavour pada makanan.

Tabel 1. Komposisi nilai gizi kerang hijau dalam 100 gram bahan

\begin{tabular}{lc}
\hline \multicolumn{1}{c}{ Komponen } & Jumlah \\
\hline Protein & $7,06-16,78 \%$ \\
Karbohidrat & $2,36-4,95 \%$ \\
Lemak & $0,40-2,47 \%$ \\
Air & $78 \%$ \\
Kalsium & $133 \mathrm{mg}$ \\
Fosfor & $170 \mathrm{mg}$ \\
Energi & $68-88 \mathrm{Kkal}$ \\
\hline
\end{tabular}

Sumber: Dore (1991) 
KERANG HIJAU SEBAGAI BIOINDIKATOR PENCEMARAN LOGAM DI PERAIRAN

Kerang hijau telah banyak digunakan ilmuwan untuk memantau pencemaran pada perairan. Salah satu sebabnya adalah kerang hijau merupakan organisme yang tersebar luas di dunia (Yap, 2004). Kerang hijau adalah salah satu bivalvia yang merupakan kerang spesifik di Benua Asia. Kerang ini hidup tersebar dari daerah Indo Pasifik, selatan perairan Jepang, perairan-perairan India, semenanjung Malaysia, Singapura, Laut Cina Selatan, Thailand, Filipina, Indonesia, hingga Papua New Guinea (Setyobudiandi, 2004).

Program "Mussel Watch" yang dicanangkan oleh dunia Internasional juga menggunakan jaringan lunak dari kerang bivalvia untuk memantau polusi perairan (Gillikin, 2005). Alasan lainnya adalah karena jenis kerang ini merupakan biota yang dalam perkembangannya menetap pada suatu tempat, berumur panjang, mudah didapatkan dan diidentifikasi, jumlahnya berlimpah dan mudah diperoleh setiap tahunnya serta tahan fluktuasi kondisi alami lingkungan dan polusi (Yap, 2004).

Kerang hijau merupakan sumber mineral yang penting $(\mathrm{Ca}, \mathrm{Fe})$ dan beberapa vitamin (niasin, thiamin, dan riboflavin) untuk tubuh manusia. Hal ini juga menguatkan alasan para ilmuwan untuk selalu meneliti biota laut ini dan menentukan batasan konsentrasi polutan yang beresiko untuk dikonsumsi manusia (Yap, 2004).

\section{PENANGANAN KERANG HIJAU}

\section{Upaya Pengurangan Logam Berat Pada Kerang Hijau}

Seperti halnya produk perikanan lain, kekerangan sering menghadapi masalah dengan pencemaran oleh logam berat. Kandungan logam berat yang tinggi ditemukan pada jenis kerang-kerangan karena organisme ini merupakan organisme invertebrata filterfeeder dan hidup menetap. Kandungan logam berat dalam daging organisme perairan biasanya lebih tinggi daripada kandungan logam berat pada perairannya, karena logam berat tersebut akan terakumulasi di dalam dagingnya (Hutagalung, 1991).

Pencemaran logam berat pada perairan merupakan salah satu pencemaran yang dapat membahayakan baik bagi organisme yang hidup di dalamnya maupun manusia yang mengkonsumsi organisme yang tercemar. Logam merkuri $(\mathrm{Hg})$ dan timbal $(\mathrm{Pb})$ termasuk golongan logam berat dengan toksisitas tinggi, begitu juga arsen (As) (Hutagalung, 1991). Jumlah logam berat yang terakumulasi dalam jaringan tubuh hewan air yang masih aman dikonsumsi manusia ditentukan dalam standar. Kep Ditjen POM No. 03725/B/SK/VII/1998 dan WHO (1976) menentukan batas maksimum kandungan logam $\mathrm{Hg}$ pada organisme laut yang boleh dikonsumsi yaitu 0,5 ppm dan untuk logam $\mathrm{Pb}$ yaitu 2 ppm (Kep. Ditjen POM No. 03725/B/SK/VII/1989 dan WHO, 1989).

Pencemaran logam berat $\mathrm{Hg}, \mathrm{Cd}$, dan $\mathrm{Pb}$ pada daging kerang hijau akan menyebabkan keracunan bagi masyarakat yang mengkonsumsinya, karena logam berat tersebut termasuk jenis logam berat yang mempunyai toksisitas tinggi dan bersifat akumulatif pada tubuh manusia yang mengkonsumsinya. Menurut LeCoultre (2001), akibat yang ditimbulkan karena keracunan logam berat merkuri antara lain kerusakan syaraf (neurotoksik) dan kerusakan pada kromosom yang dapat mengakibatkan kemandulan (terotoksik). Keracunan logam berat timbal akan menyebabkan kerusakan paru-paru dan kerusakan syaraf, sedangkan akibat yang ditimbulkan oleh keracunan kadmium adalah kerusakan hati, ginjal, paru-paru, dan tulang, serta bersifat karsinogen. Oleh karena itu, perlu adanya suatu upaya untuk menurunkan kandungan logam berat pada kerang hijau sehingga pengaruh negatif terhadap kesehatan masyarakat yang mengkonsumsinya dapat dicegah secara dini.

Berbagai metode seperti penukaran ion, penyerapan dengan karbon aktif, dan pengendapan secara elektrolisis telah dilakukan untuk menyerap bahan pencemar beracun, tetapi cara ini membutuhkan biaya yang besar dalam pengoperasiannya (Marganof, 2003).

Irwansyah (1995), menyatakan bahwa salah satu upaya menurunkan kadar logam berat pada daging kerang hijau yaitu dengan cara merendam daging kerang tersebut dalam larutan dinatrium etilen diamin tetra-asetat dan kitosan karena kedua zat ini mempunyai kemampuan untuk mengikat ion logam berat dan menariknya keluar jaringan. Perendaman daging kerang hijau dalam larutan kitin sebesar $5 \%$ selama 30 menit dapat menurunkan kandungan merkuri sebesar 34\% dari kandungan kerang tanpa penambahan kitin (Irwansyah, 1995). Murtini et al. (2004), mengatakan bahwa konsentrasi larutan kitosan 1,5\% dengan lama perendaman 3 jam cukup efektif mereduksi logam berat $\mathrm{Hg}$ sebesar $94,89 \%$ dan logam $\mathrm{Pb}$ sebesar $96,48 \%$ daging kerang hijau. Berdasarkan sifat-sifat yang dimiliki kitosan sebagai adsorben logam berat, Murtini et al. ( 2008) mengembangkan penggunaan karboksimetil kitosan yang merupakan salah satu senyawa derivat dari kitosan yang mampu larut dalam air dan tidak beracun. Perlakuan perendaman larutan karboksimetil kitosan menggunakan konsentrasi 0; 0,5; 1 ; dan 1,5\% dengan lama perendaman 1, 2, dan 3 jam. Perlakuan yang 
paling efektif untuk menurunkan logam berat $\mathrm{Hg}$ adalah perendaman dengan larutan karboksimetil kitosan $0,5 \%$ selama $1 \mathrm{jam}$, sedangkan perendaman dengan larutan karkoksimetil kitosan $0,5 \%$ selama 3 jam paling efektif menurunkan logam berat $\mathrm{Pb}$. Widiyanti (2004), mengatakan bahwa perendaman daging rebus kerang hijau dalam larutan asam (cuka 5\%, asam jawa $5 \%$, dan jeruk nipis) selama perendaman 30 menit dapat menurunkan kandungan logam berat merkuri pada kerang hijau masing-masing sebesar $76,63 \%$; 70,94\%; dan 70,89\%. Menurut Suaniti (2007), perlakuan perendaman daging kerang hijau dalam larutan EDTA 0,1M pada $\mathrm{pH} 4$ selama 30 menit dapat menurunkan kandungan logam berat $\mathrm{Pb}$ pada daging kerang hijau sebesar $4,91 \%$ dan logam berat Cu sebesar $84,32 \%$.

\section{Depurasi Kerang Hijau}

Masalah utama dalam pengembangan perikanan kerang untuk tujuan konsumsi adalah terjadinya kontaminasi bakteri selama kerang tumbuh di alam bebas atau dipelihara. Hal ini berkaitan dengan lingkungan hidup kerang yang merupakan tempat terkumpulnya limbah manusia sehingga berpotensi sebagai sumber kontaminan yang berbahaya karena peluang adanya bakteri patogen dan virus penyebab penyakit cukup besar (Souness, 1979; Fujioka et al., 1981). Sifat filter feeder dari kerang mengakibatkan beberapa mikroba termasuk bakteri-bakteri patogen terakumulasi dalam tubuhnya dengan kadar jauh lebih tinggi daripada air lingkungan tempat hidupnya. Hal ini menyebabkan kerang dapat menjadi bahan makanan yang berbahaya karena dapat menularkan penyakit.

Beberapa penyakit yang disebabkan oleh bakteri maupun virus pernah dilaporkan, penularannya melalui produk olahan shellfish termasuk kerang. Di antara bakteri tersebut termasuk Salmonella $s p$, Vibrio parahaemolyticus, Vibrio cholera, Clostridium perfringens, dan Staphylococcus aureus. Sedangkan virus, antara lain virus hepatitis dan virus Norwalk yang dapat menimbulkan penyakit perut (Souness, 1979). Bakteri E. Coli telah disepakati oleh ICMSF (International Commision Microbiology Specification for Food) sebagai salah satu parameter mutu mikrobiologis dari suatu produk perikanan termasuk kerang (FAO dan WHO, 1975). Produk kerang yang memenuhi standar tersebut diasumsikan tidak mengandung bakteri patogen sehingga tidak berbahaya bagi konsumen (Peranginangin, 1985). Standar maksimum kandungan bakteri $E$.Coli kerang yang diusulkan oleh beberapa negara merupakan salah satu upaya higiene yang bertujuan untuk mengurangi resiko kerang sebagai penular penyakit. Menurut Souness (1979), upaya higiene dapat dilakukan dengan depurasi, yaitu suatu proses pencucian bakteri dari dalam kerang dengan menggunakan alat mekanis.

Bakteri-bakteri dalam kerang dapat dikurangi atau ditiadakan sama sekali dengan cara depurasi. Depurasi adalah suatu proses pencucian kerang, sehingga kerang yang tercemar dapat tercuci dengan sendirinya dari pencemar mikroba dalam bak-bak yang berisi air laut steril. Air laut disterilkan oleh unit sterilisasi, kemudian dimasukkan kembali ke dalam bak-bak tempat kerang berada. Sirkulasi air laut berjalan terus selama depurasi berlangsung sekitar 48 jam (Peranginangin et al., 1984a; Peranginangin et al., 1984b). Komponen utama dari suatu alat depurasi kerang adalah unit sterilisasi. Efektivitas alat depurasi dipengaruhi oleh daya bunuh unit sterilisasi terhadap mikroba. Daya bunuh unit ini dipengaruhi oleh metode atau bahan sterilisasi yang digunakan dan sifat limnologis air yang disterilkan. Teknologi depurasi terhadap kerang hijau dalam skala laboratorium menggunakan unit sterilisasi air dari cahaya ultraviolet 90 watt dengan suhu air $26-28^{\circ} \mathrm{C}$ dalam waktu 48 jam depurasi, dapat menurunkan jumlah bakteri awal $10^{7} \mathrm{sel} / \mathrm{gram}$ menjadi $10^{5} \mathrm{sel} /$ gram, coliform dari $82 \mathrm{sel} / \mathrm{gram}$ menjadi $8,9 \mathrm{sel} / \mathrm{gram}$ dan $E$. Coli dari $45 \mathrm{sel} / \mathrm{gram}$ menjadi 1,79 sel/gram (Peranginangin et al., 1984a). Dari hasil penelitian skala laboratorium kemudian dikembangkan konstruksi alat depurasi kerang-kerangan skala semi komersial oleh Perangin-angin et al. (1985). Depurasi kerang hijau di Panimbang, Banten pertama kali di Indonesia karena di daerah lain belum ada, sehingga pemerintah provinsi Banten akan menjadikan depurasi ini sebagai pilot project di Indonesia (Anon., 2007).

\section{PRODUK-PRODUK OLAHAN KERANG HIJAU}

\section{Kamaboko}

Kamaboko merupakan makanan yang berasal dari Jepang, yang terbuat dari gel protein ikan atau surimi. Beberapa produk yang dapat diolah dari surimi seperti kamaboko, chikuwa, bakso, sosis, udang tiruan. Pengembangan produk kamaboko yang dibuat dari surimi kerang hijau telah dilakukan oleh Sobana (2005). Untuk menghasilkan surimi, kerang hijau pertama-tama dicuci untuk menghilangkan kotoran, kemudian dikupas untuk memisahkan daging dari cangkangnya. Daging kerang selanjutnya dibersihkan dari kotoran dan dicuci, digiling dengan food processor. Daging lumat dicuci dengan air es dengan rasio daging kerang dan air es adalah 1:3, didiamkam selama 5 menit, lalu diperas untuk mengurangi air. Pencucian dilakukan satu kali. Surimi yang dihasilkan kemudian diaduk menggunakan food 
processor dengan penambahan $\mathrm{NaCl} 0,3 \%$. Selanjutnya surimi siap digunakan sebagai bahan baku produk kamaboko.

Proses pembuatan kamaboko kerang hijau dilakukan dengan menggunakan metode Suzuki (1981) yang dimodifikasi. Resep yang digunakan untuk membuat kamaboko terdiri dari surimi daging kerang hijau, tepung tapioka $5 \%$, garam $2,5 \%$, dan bumbu $2 \%$. Bumbu adalah campuran dari bawang putih, bawang merah, dan merica dengan rasio 3:15:1.Semua persentase didasarkan pada berat surimi daging kerang hijau. Pada pengolahan kamaboko, surimi daging kerang hijau ditambah tepung tapioka, bumbu, dan garam. Kemudian diaduk mengunakan food processorselama 5 menit. Adonan kemudian dicetak, direbus pada suhu setting $40^{\circ} \mathrm{C}$ selama 20 menit dan dilanjutkan dengan cooking dengan suhu $90^{\circ} \mathrm{C}$ selama 30 menit. Komposisi proksimat kamaboko kerang hijau dapat dilihat pada Tabel 2.

Berdasarkan komposisi proksimat kamaboko kerang hijau kandungan proteinnya cukup tinggi, yaitu $21,13 \%$. Dengan demikian, kamaboko kerang hijau dapat dijadikan sumber protein hewani.

\section{Hidrolisat Protein}

Hidrolisat protein adalah produk pangan yang komponen utamanya adalah protein yang telah mengalami hidrolisis oleh perlakuan asam kuat, basa kuat, atau enzim. Hidrolisat protein pertama kali dikomersialkan di Cina dan Jepang sekitar tahun 1990, merupakan hasil samping pembuatan monosodium glutamat (MSG). Hidrolisat protein memiliki kandungan protein yang tinggi. Pada industri pangan hidrolisat protein dapat ditambahkan dalam formula nonalergenik untuk bayi dan suplemen makanan diet (Pigot \& Tucker, 1990). Pembuatan hidrolisat protein dari daging kerang hijau dengan menggunakan papain telah dilaporkan oleh Amalia (2007). Tahap-tahap proses pembuatan hidrolisat protein dari daging kerang hijau sebagai berikut: daging kerang hijau dicincang, lalu dicampur dengan air dengan perbandingan 1:4 dan ditambah enzim papain dengan konsentrasi 5\% (berat/volume). Proses hidrolisis dilakukan pada suhu $55^{\circ} \mathrm{C}$, $\mathrm{pH} 6$ (dengan penambahan $\mathrm{CH}_{3} \mathrm{COOH}$ untuk mengatur $\mathrm{pH}$ ), selama 24 jam. Setelah proses hidrolisis selesai, hidrolisat dilakukan pemanasan pada suhu $90^{\circ} \mathrm{C}$ selama 20 menit untuk menginaktifkan enzim, lalu disaring. Filtrat yang diperoleh dipekatkan menggunakan alat freeze driyer. Komposisi proksimat hidrolisat protein kerang hijau disajikan pada Tabel 3.

Kandungan asam amino produk hidrolisat ini adalah asam aspartat, asam glutamat, serin, glisin, histidin, arginin, treonin, alanin, prolin, tirosin, valin, methionin, sistin, isoleusin, leusin, phenilalanin, dan lisin. Nilai daya cerna produk ini $78,93 \%$. Produk

Tabel 2. Komposisi proksimat kamaboko kerang hijau

\begin{tabular}{lc}
\hline \multicolumn{1}{c}{ Parameter } & Nilai \\
\hline Kadar air (\%) & 68,62 \\
Kadar protein (\%) & 21,13 \\
Kadar lemak (\%) & 0,28 \\
Kadar abu ( \%) & 1,71 \\
\hline
\end{tabular}

Sumber: Sobana (2005)

Tabel 3. Komposisi proksimat hidrolisat protein kerang hijau

\begin{tabular}{lc}
\hline \multicolumn{1}{c}{ Parameter } & Nilai \\
\hline Kadar air (\% ) & 84,44 \\
Kadar abu (\% ) & 1,57 \\
Kadar protein (\%) & 7,97 \\
Kadar lemak (\%) & 1,67 \\
\hline
\end{tabular}

Sumber: Amalia (2007) 
hidrolisat protein kerang hijau dapat dijadikan alternatif sebagai bahan fortifikasi pada produk makanan bayi atau suplemen pada makanan diet untuk meningkatkan asupan protein.

\section{PRODUK CONDIMENT}

Condiment berupa saus kental berwarna agak kehitaman dalam masakan Tionghoa yang dibuat dari bahan dasar tiram dan mempunyai rasa gurih dan asin. Condiment merupakan bahan masakan Cina klasik yang pada dasarnya terbuat dari campuran kerang, air, dan garam, namun dalam perkembangannya sudah banyak mengalami banyak modifikasi (Jiang et al., 2006). Condiment biasanya dimanfaatkan sebagai penambah rasa dan penguat aroma makanan (Harold, 2004). Beberapa produk condiment yang digunakan sebagai flavor telah banyak dipatenkan, diantaranya paten nomor EP0699667B1 yang berjudul Amino acid derivatives of creatinine as seasoning material dengan inventor Shima et al. (1996), nomor paten EP0824873B1 berjudul Production of seasoning oleh Baensch et al. (1996), dan Fukushima et al. (1997) dengan nomor paten EP00846423A1 berjudul Process for producting seasoning. Mundakir (2008) telah meneliti proses pembuatan pasta condiment dengan bahan dasar kerang hijau (Perna viridis) dengan penambahan ekstrak nenas (Ananas cosmosus). Proses pembuatan pasta condiment kerang hijau diawali dengan penyiangan kerang yaitu daging kerang dipisahkan dari cangkangnya. Daging kerang dicuci sampai bersih kemudian digiling dengan alat penggiling daging. Daging kerang yang sudah digiling ditambah garam halus $25 \%$ dan ekstrak nanas $10 \%$ dari berat daging lalu dicampur sampai homogen, kemudian difermentasi selama 21 hari. Setelah proses fermentasi dilakukan penyaringan dan filtrat yang diperoleh ditambah bumbu dimasak pada suhu 70$80^{\circ} \mathrm{C}$ selama 15 menit. Bumbu yang ditambahkan sebanyak $64 \%$ yang terdiri dari ketumbar $7,7 \%$; gula merah $13 \%$; lengkuas $12,5 \%$; bawang putih $18,5 \%$; kunyit $12,3 \%$, dan air $100 \mathrm{~mL}$. Setelah dimasak kemudian disaring dan diperoleh pasta condiment kerang hijau. Komposisi kimia pasta condiment kerang hijau dapat dilihat pada Tabel 4.

Condiment kerang hijau mengandung 15 jenis asam amino. Asam amino yang mendominasi adalah asam glutamat $(9,37 \%)$, glisin $(8,24 \%)$, alanin $(8,11 \%)$, dan lisin (8,24\%). Menurut Young et al. (2004) dalam condiment kerang sebagian besar asam amino tersebut merupakan kontributor utama dalam pembentukan flavour condiment kerang hijau. Sebagai bahan pangan, asam amino jenis serin, glisin, alanin dan valin memiliki rasa manis dan rasa gurih disebabkan oleh asam glutamat. Salah satu produk olahan kerang yang saat ini mulai berkembang adalah pasta kerang, termasuk produk pasta condiment yang dibuat melalui proses fermentasi.

\section{Kerupuk}

Kerupuk ikan dan kerupuk udang merupakan produk olahan hasil perikanan yang sangat populer di Indonesia. Produk tersebut banyak diproduksi di Palembang, Bangka, dan Sidoarjo. Widiyanti (2004) telah mempelajari pembuatan kerupuk dari kerang hijau. Pada pembuatan kerupuk kerang hijau, daging kerang hijau yang telah dihancurkan dicampur dengan tepung tapioka $(66,7 \%)$, telur (1 butir), ketumbar $(0,67 \%)$, bawang putih $(3 \%)$, garam $(5 \%)$, gula pasir secukupnya, air panas (150 mL), dan diaduk sampai homogen. Adonan yang telah dicetak kemudian dikukus selama 2 jam lalu didinginkan selama 24 jam. Setelah dingin diiris dan dikeringkan. Komposisi proksimat kerupuk kerang hijau seperti tertera pada Tabel 5.

Kerupuk kerang hijau merupakan salah satu inovasi baru produk olahan perikanan yang dapat meningkatkan pemanfaatan kerang hijau sebagai

Tabel 4. Komposisi kimia pasta condiment kerang hijau

\begin{tabular}{lc}
\hline \multicolumn{1}{c}{ Parameter } & Nilai \\
\hline Kadar air (\% ) & 57,36 \\
Kadar abu (\%) & 5,52 \\
Kadar protein (\%) & 10,51 \\
Kadar lemak (\%) & 5,39 \\
Kadar NPN (\%) & 31,29 \\
\hline
\end{tabular}

Sumber: Mundakir (2008) 
Tabel 5. Komposisi proksimat kerupuk kerang hijau

\begin{tabular}{ll}
\hline \multicolumn{1}{c}{ Parameter } & Nilai \\
\hline Kadar air (\%) & 7,73 \\
Kadar abu (\%) & 7,07 \\
Kadar protein (\%) & 7,02 \\
Kadar lemak (\%) & 0,51 \\
\hline
\end{tabular}

Sumber: Widiyanti (2004)

sumber protein masyarakat, mengingat produk kerupuk sudah dikenal dan sangat disukai oleh masyarakat, terutama sebagai makanan camilan.

\section{Kerang hijau rebus}

Daging kerang hijau merupakan sumber protein dan mineral sehingga memiliki potensi yang bagus sebagai bahan pangan manusia. Kerang hijau biasa dikonsumsi masyarakat sebagai kerang rebus, yang diberi bumbu dan dijual dengan gerobak keliling. $\mathrm{Di}$ pasar atau supermarket kerang hijau dijumpai dalam bentuk daging kerang yang berwarna kuning, oranye, atau merah. Warna daging kerang tersebut diduga berasal dari pewarna nonpangan yang digunakan oleh para produsen. Untuk mengatasi masalah pada cara pengolahan kerang hijau rebus telah dilakukan penelitian penggunaan bahan pewarna alami yang aman untuk dikonsumsi. Murdinah (2008) mengemukakan bahwa kunyit dan angkak dalam bentuk bubuk dapat digunakan sebagai bahan pewarna alami untuk pengolahan kerang hijau rebus. Cara pengolahan kerang hijau rebus dengan menggunakan bahan pewarna alami adalah sebagai berikut: kerang hijau dicuci sampai bersih, lalu direbus selama 45 menit (kerang: air $=1: 1$ ). Setelah direbus daging kerang dipisahkan dari cangkangnya. Daging kerang hijau rebus lalu direndam dalam larutan kunyit atau angkak $1 \%$ selama perendaman 45 menit, kemudian dicuci dan ditiriskan. Daging kerang hijau rebus dengan bahan pewarna alami ini aman dikonsumsi sebagai sumber protein dan mineral.

\section{PROSPEK PENGEMBANGAN KERANG HIJAU DI INDONESIA}

Dalam pengembangan budidaya laut (marikultur) di Indonesia, selain komoditas ikan dan udang , masih ada komoditas lain yang mempunyai prospek bagus, yaitu berbagai jenis keluarga kerang. Jenis kekerangan ini cukup banyak yang bisa dikembangbiakkan melalui teknik marikultur, yaitu tiram, kerang hijau, kerang darah, tiram mutiara, abalon, dan siput.
Keluarga kerang merupakan sumberdaya hayati laut yang banyak tersedia di perairan Indonesia. Biota ini bisa di budidayakan dan bersifat ramah lingkungan, antara lain karena dalam proses budidayanya tidak memerlukan pakan . Kegiatan marikultur untuk kerangkerangan adalah sebagai berikut: manipulasi genetika, kontrol predator, penyakit, pengumpulan benih, pembenihan di hatcheri, kebutuhan/persyaratan nutrisi, pemilihan lokasi, pemanenan, depurasi, dan perlengkapan budidayanya (Anon., 2006e).

Kerang hijau merupakan salah satu jenis kerang yang memenuhi syarat untuk dibudidayakan di perairan pantai. Sebagai hewan pemakan plakton, kerang hijau menempati posisi di bawah dalam rantai makanan, mampu memanfaatkan secara ekonomis produksi primer yang ada di perairan pantai. Dilihat dari proses budidayanya, kerang akan menghasilkan protein hewani yang murah dibandingkan jenis biota perairan lainnya. Kerang hijau mengandung protein cukup tinggi, rata-rata $67 \mathrm{~g}$ per $100 \mathrm{~g}$ bobot kering. Nilai ini sangat menguntungkan dibandingkan jenis makanan tradisional lainnya, seperti daging sapi atau ayam. Betapa penting, kerang hijau sebagai sumber protein hewani yang murah, khususnya bagi masyarakat berpenghasilan rendah.

Kebutuhan pasar akan produk kekerangan sangat terbuka besar. Berapapun jumlah yang di produksi selalu siap diterima untuk mencukupi pasar domestik. Sementara pasar luar negeri sampai saat ini relatif belum tersentuh. Padahal kebutuhan negara-negara maju seperti Amerika, Jepang, dan Uni Eropa akan protein hewani kerang sangat tinggi. Pasar Korea juga mulai melirik kerang hijau dari Cirebon. Kerang hijau yang diminta berdiameter 7-8 $\mathrm{cm}$ atau berusia sekitar 7 bulan (Anon., 2009b). Kerang hijau sebagai sumber protein hewani, memiliki potensi yang cukup prospektif sebagai komoditi ekspor. Untuk itu, beberapa hal perlu diperhatikan adalah budidaya kerang hijau harus ramah lingkungan, lokasi kawasan pengembangan budidaya harus bebas dari pencemaran limbah logam berat seperti tembaga $(\mathrm{Cu})$, 
merkuri $(\mathrm{Hg})$, seng $(\mathrm{Zn})$, kadmium $(\mathrm{Cd})$ dan bebas dari pencemaran limbah rumah tangga seperti kritis oksigen terlarut dan banyak mengandung bakteri Salmonella, Echericia coli, Clostridium, dan Shigella. Selain itu perlu juga diperhatikan teknik depurasi, sanitasi, dan higienis penanganan pascapanen dan pengolahan. Dengan demikian diharapkan jumlah ekspor kerang hijau ke luar negeri makin bertambah dan bagi dunia internasional kerang hijau dari Indonesia aman dikonsumsi dan tidak membahayakan kesehatan orang yang mengkonsumsinya.

\section{PENUTUP}

Potensi kerang hijau sebagai sumber makanan masyarakat di Indonesia cukup tinggi . Kerang hijau merupakan salah satu dari kelompok shellfish yang telah banyak dibudidayakan dan dapat dipanen setelah berumur 6-7 bulan. Terdapat dua jenis kerang hijau yaitu Mytilus viridis dan Perna viridis. Kerang hijau mengandung protein $16,7-21,9 \%$, kaya akan asam amino esensial (arginin, leusin, lisin) dan mengandung mineral kalsium, fosfat, yodium, tembaga. Berdasarkan kandungan nilai gizinya yang tinggi, kerang hijau dapat dimanfaatkan sebagai sumber protein hewani yang relatif murah dibandingkan ikan.

Penanganan kerang hijau agar aman dikonsumsi dapat dilakukan dengan cara pengurangan kandungan logam berat dan teknik depurasi untuk menurunkan kandungan bakteri kerang hijau. Konsentrasi larutan kitosan $1,5 \%$ dengan lama perendaman 3 jam cukup efektif mereduksi logam berat $\mathrm{Hg}$ sebesar $94,89 \%$ dan logam $\mathrm{Pb}$ sebesar $96,48 \%$ dari daging kerang hijau. Perendaman dalam larutan kitin 5\% selama 30 menit dapat menurunkan kandungan merkuri $(\mathrm{Hg})$ sebesar $34 \%$, sedangkan perendaman dalam larutan asam cuka $5 \%$ selama 30 menit dapat menurunkan kandungan merkuri sebesar $76,63 \%$. Perendaman daging kerang hijau dalam larutan EDTA $0,1 \mathrm{M}$ pada $\mathrm{pH} 4$ selama 30 menit dapat menurunkan kandungan logam berat $\mathrm{Pb}$ sebesar $4,91 \%$ dan $\mathrm{Cu}$ sebesar $84,32 \%$. Teknik depurasi pada kerang hijau dengan menggunakan unit sterilisasi air dengan cahaya ultraviolet 90 watt selama 48 jam dapat menurunkan bakteri awal dari $10^{7}$ menjadi $10^{5} \mathrm{sel} / \mathrm{gram}$.

Pengembangan pemanfaatan kerang hijau sebagai bahan pangan dapat dilakukan dengan melakukan divesifikasi produk olahan kerang. Produk inovatif olahan kerang hijau yang telah dibuat adalah kamaboko, hidrolisat protein, pasta condiment, kerupuk, dan kerang rebus dengan pewarna alami kunyit/angkak. Pemanfaatan kerang hijau menjadi produk-produk baru ini diharapkan dapat meningkatkan konsumsi kerang hijau sebagai sumber protein. Selain itu juga akan merupakan lahan bisnis baru yang prospektif dan turut mensukseskan program pengembangan produk hasil perikanan. Kerang hijau hasil budidaya ramah lingkungan, selain berpotensi sebagai sumber protein hewani yang bermutu tinggi bagi masyarakat Indonesia juga memiliki peluang sebagai komoditi ekspor.

\section{DAFTAR PUSTAKA}

Anonim. 2006a. Keragaman dan Sebaran Budidaya Kerang Hijau di Perairan Teluk Jakarta. Dinas Peternakan dan Perikanan Kelautan.

Anonim. 2006b. Nelayan beralih ke kerang hijau. www. ppk.lipi.go.id. Diakses pada tanggal 16 September 2009.

Anonim. 2006c. Banten, Sentra budidaya kekerangan di Indonesia. www.madani-ri.com. Diakses pada tanggal 16 Septembar 2009.

Anonim. 2006d. Kerang hijau bermanfaat namun mengkhawatirkan. http.//www.kompas.com/. Diakses pada tanggal 16 September 2009.

Anonim. 2006e. Budidaya kerang ramah lingkungan. www.Balipost.co.id. Diakses pada tanggal 26 Oktober 2009.

Anonim. 2007. Depurasi kerang hijau belum optimal. www.radar banten.com. Diakses pada tanggal 26 Oktober 2009.

Anonim. 2008. Menjaring kerang hijau. Kompas. www. kompas.com. Diakses pada tanggal 16 September 2009.

Anonim. 2009a. Budidaya kerang hijau (Perna viridis). www.indonesia.go.id. Diakses pada tanggal 26 Oktober 2009.

Anonim. 2009b. Kerang hijau mulai dipanen. www.kompas.com. Diakses pada tanggal 16 September 2009.

Amalia, E. 2007. Pemanfaatan Kerang (Mytilus viridis) Dalam Pembuatan Hidrolisat Protein Menggunakan Enzim Papain. Skripsi. Fakultas Perikanan dan IImu Kelautan. IPB. Bogor: 52 pp.

Arifin, Z. dan Setyono, D.E.D. 1992. Potensi sumberdaya kekerangan dan prospek pengembangannya di Maluku. Prosiding Lokakarya Ilmiah Potensi Sumberdaya Perikanan Maluku, No. 8. Balitbang Perikanan Budidaya Pantai, Maros : 77-86.

Asikin. 1982. Kerang Hijau. Penebar Swadaya Jakarta.

Baensch J, Gaier W, Khoo HGN, Lai HL, Lim BG. 1996. The production of seasoning. European Patent Specification. EP 0824873 B1.

Chen, F.Y. 1977. Preliminary Observations of Mussel culture in Singapore. Asean Meeting of Experts on Aquaculture. Semarang Indonesia 31Januari-6 Februari 1977.

Dharma, B. 1988. Siput dan Kerang Indonesia I (Indonesian shells). Sarana Graha, Jakarta. 111 pp.

Direktorat Jendral Pengawasan Obat dan Makanan. 1989. Standarisasi Pengawasan Perikanan dan Hasil Perikanan. Direktorat Jendral Pengawasan 
Obat dan Makanan, Departemen Kesehatan, Jakarta. P. $1.1-4.6$

Dody, S. 2004. Biologi reproduksi limpet tropis (Cellana testudinaria Linnaeus, 1758) di Perairan Pulaupulau Banda, Maluku. Disertasi. IPB. Bogor: 143 pp.

Dore I. 1991. Shellfish. A. Guide Oyster, Mussels, Scallops, Clamps and Similar product for The Commercial User. Van Nostrand Reinhold/Osprey Books. New York.

FAO. 1996. FAO yearbook vol. 82. Fishery statistic. Capture production. FAO, Rome.148 pp.

Food and Agricultural Organization, World Health Organization and United Nations Environment Programme). 1975. Report of The Joint FAO/WHO Expert Consultation Microbiological Specification for Food in Geneve. Publications Division, FAO, Rome. $82 \mathrm{pp}$.

Fukushima Y, Okayasu M, and Sugishita M. 1997. Processing for producing seasoning. European Patent Specification. EP0846423 A1.

Fujioka, R.S., H.H. Hashimoto, E.B. Siwak and R.H.F. Young .1981. Effect of sunlight on survival of indicator bacteria in seawater. Appl. Environ. Microbiol. 41: 690-696.

Gillikin DP . 2005. Inter-and intra-annual variations of $\mathrm{Pb} / \mathrm{Ca}$ ratios in clam shells (Mercenaria mercenaria): A record of anthropogenic lead pollution?. Marine Pollution Bulletin, in press.

Harold, M. 2004. On Food and Cooking . New York: Condiment. www. Wikipedia.org. Diakses pada tanggal 1 April 2007.

Hutagalung, H.P. 1991. Pencemaran Laut oleh Logam Berat dalam Beberapa Perairan Indonesia. Puslitbang Oseanologi LIPI, Jakarta. p. 1-20.

Irwansyah. 1995. Efektifitas Kitin Sebagai bahan Pengabsorpsi Residu Logam Berat Raksa (Hg) pada Kerang Hijau (Mytilus viridis ). Skripsi, Fakultas Perikanan dan Kelautan, IPB, Bogor. 65 pp.

Jiang JJ., Zang QX, Zhu ZW, and Zhang LY. 2006. Chemical and sensory changes associated Yu-Lu fermentation process-A tradisional Chinese fish sauce. J. Food Chemistry. 104:1629-1634.

Kastoro W. 1982. Beberapa aspek biologi kerang hijau (Mytilus viridis) dari Perairan Binaria Ancol Teluk Jakarta. Tesis. Jakarta. Universitas Nasional.

LeCoultre, T.D. 2001. A Meta-analysis and Risk Assesment of Heavy Metal Uptake In Common Garden Vegetables. Thesis. Faculty of the Department of Environmental Health, East Tennessee State University, US. 64 pp.

Marganof. 2003. Potensi Limbah Udang Sebagai Penyerap Logam Berat (Timbal, Kadmium, dan Tembaga) di Perairan. Unpublished. Pengantar ke Falsafah Sains Program Pascasarjana S3 IPB, Bogor, $8 \mathrm{pp}$.

Mundakir. 2008. Karakteristik Kimia Condiment Kerang Hijau (Perna viridis) Hasil Pengolahan Dengan Penambahan Ekstrak Nenas (Ananas cosmosus).
Skripsi. Fakultas Perikanan dan IImu Kelautan, IPB, Bogor. $81 \mathrm{pp}$.

Murdinah. 2008. Pengolahan kerang hijau (Mytilus viridis) menggunakan bahan pewarna alami. Prosiding Seminar Widyakarya Nasional Pangan dan Gizi IX. LIPI. Jakarta.

Murtini, J.T., Januar, H.I., dan Sugiyono. 2004. Upaya pengurangan cemaran logam berat pada daging kerang hijau (Perna viridis) dengan menggunakan larutan kitosan. J. Penel. Perik. Indonesia Edisi Pasca Panen. Pusat Riset Pengolahan Produk dan Sosial Ekonomi Kelautan dan Perikanan, Jakarta. 10(3): p. 7-10.

Murtini, J.T., Kurniawan, A.D., dan Dewi, E.N. 2008. Pengaruh waktu perendaman dan konsentrasi karboksimetil kitosan untuk menurunkan kandungan logam berat $\mathrm{Hg}$, Cd, dan $\mathrm{Pb}$ Pada Kerang Hijau (Perna viridis Linn.). Jurnal Pascapanen dan Bioteknologi Kelautan dan Perikanan, Jakarta. 3 (1): p. $37-43$.

Peranginangin, R. 1985. Pentingnya penetapan standar untuk kerang dan areal budidaya laut. Petunjuk Praktis Bimbingan dan Pengujian Mutu Hasil Perikanan. IV (12/13): p. 8-11.

Peranginangin, R., Sumpeno Putro , Suyuti Nasran, dan Jovita Tri Murtini. 1984a. Depurasi kerang hijau (Mytilus viridis Linn). Laporan Penelitian Teknologi Perikanan (37): p. 17-26.

Peranginangin, R., Sumpeno Putro, Memen Suherman, dan Suparno. 1984b. Konstruksi Serta Efektivitas Depurasi Terhadap Bakteri E. Coli. Laporan Penelitian Teknologi Perikanan (38): p. 9-16.

Peranginangin, R., Sumpeno Putro, Memen Suherman, dan Suyuti Nasran. 1985. Konstruksi alat depurasi kerang-kerangan skala semi komersial. Laporan Penelitian Teknologi Perikanan. (47): p. 17-24.

O. Sullivan G. 2003. Mussel Market Report-August 2003.www.globefish.org. Assessed October 26, 2009.

Pigot G.M and Tucker BW. 1990. Utility fish flesh effectively while maintaining nutritional qualities. Seafood Effects of Teechnology on Nutrion. New York: Marcel Decker, Inc.

Sanusi, H.S, Hutagalung, H., dan Razak, H. 1964. Hubungan antara umur, kadar air,raksa $(\mathrm{Hg})$ dan cadmium (Cd) yang terakumulasi oleh kerang hijau (Mytilus viridis L) yang dibudidayakan di perairan Teluk Jakarta. Laporan Penelitian. Bogor. Jurusan Manajemen Sumberdaya Perairan, Fakultas Perikanan, IPB.

Setyobudiandi I. 2004. Beberapa Aspek Biologi Reproduksi Kerang Hijau Perna viridis Linnaeus, 1978 Pada Kondisi Perairan Berbeda . Disertasi. Bogor: Sekolah Pascasarja, Institut Pertanian Bogor.

Shima K, Harada T, Suzuki E, Honda Y. 1996. Amino acid derivatives of creatinine as seasoning material. European Patent Specification. EP 0699667 B1.

Sobana. 2005. Pemanfaatan Daging Kerang Hijau (Perna viridis L) Dalam Pembuatan Produk 
Kamaboko. Skripsi. Fakultas Perikanan dan IImu Kelautan. IPB. Bogor. 87 pp.

Souness, R. Depuration of The Sydney Rock Oyster (Crassostrea commercialis). 1979. The University of New South Wales School of Food Technology, Australia. 119 pp.

Suzuki. T. 1981. Fish and Kril Protein: Processing Technology. London. Aplied Science Ltd.

Suaniti, N,M. 2007. Pengaruh EDTA dalam penentuan timbal dan tembaga pada kerang hijau (Mytilus viridis). ECOTROPHIC 2(1): 1 Mei 2007. 7 pp.

WHO. 1976. Mercury, Environmental Health Criteria I. WHO, Geneva.130 pp.

WHO. 1989. Lead, Environmental Health Criteria 85. WHO, Geneva. 106 pp.
Widiyanti, S. 2004. Reduksi Kadar Merkuri pada Kerang hijau (Mytilus viridis) di Cilincing Jakarta Melalui Metode Asam Serta Pemanfaatannya Dalam Produk Kerupuk. Skripsi. Fakultas Perikanan dan IImu Kelautan, IPB.Bogor. 105 pp.

Yap. 2004. Heavy metal (Cd, Cu, Pb, and Zn) concentrations in the green-lipped mussel Perna viridis (Linnaeus) collected from some wild and aquaculture sites in the west coat of Peninsular Malaysia. Food Chemistry 84: 569-575.

Young J, Park PJ, Jung WK, and Kim SK. 2004. Amino acid changes in fermented oyster (crasssostrea gigas) sauce with different fermentation period. J. Food Chemistry.91: 15-18.

Zaitsev VPM, Kizevetter, Lagunov L, MakarovaY, Minder $\mathrm{L}$ and Podsevalop. 1969. Fish Curing Processing. Moscow:MIR Publishing. 